Working Paper No. 60 - March 2011

ARE YOU TALKING TO US? - HOW SUBNATIONAL GOVERNMENTS RESPOND TO GLOBAL SUSTAINABLE DEVELOPMENT GOVERNANCE

\title{
Sander Happaerts
}

Paper prepared for the 2011 ISA Annual Convention, 16-19 March 2011, at Montreal.

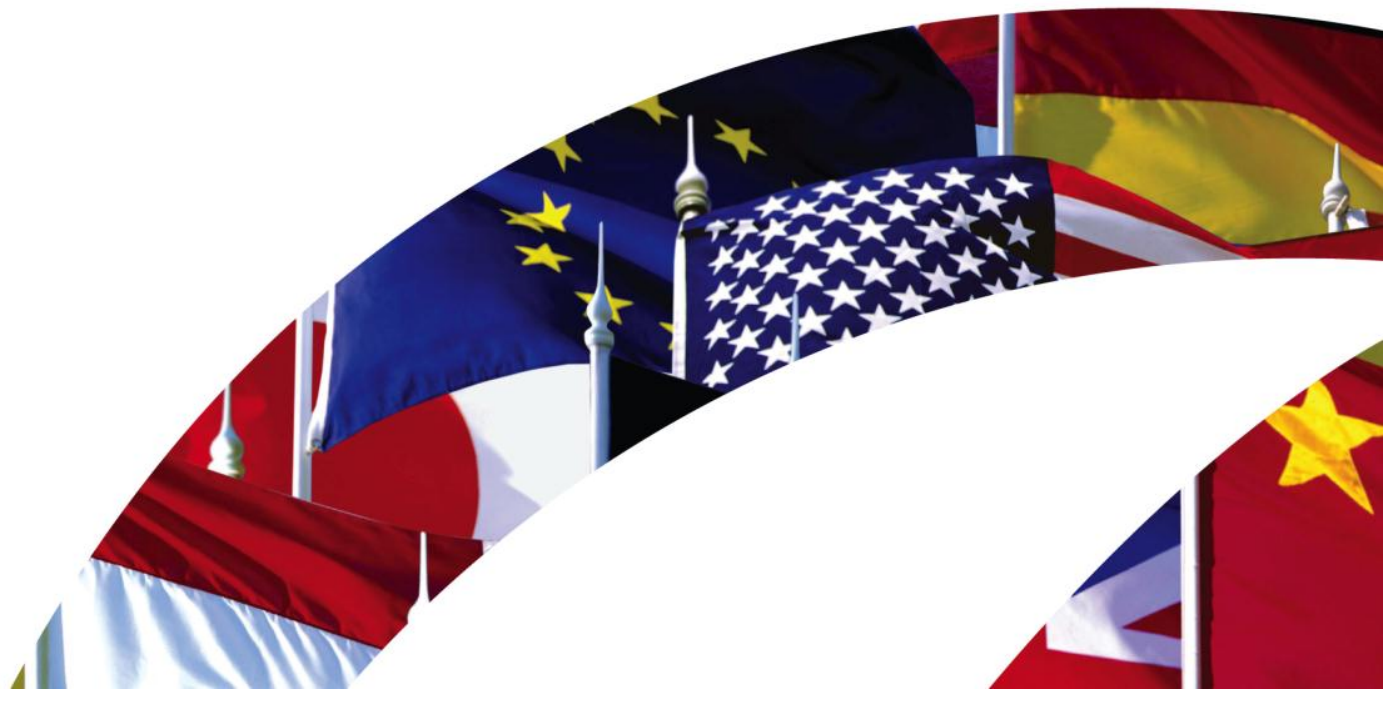




\title{
ARE YOU TALKING TO US? - HOW SUBNATIONAL GOVERNMENTS RESPOND TO GLOBAL SUSTAINABLE DEVELOPMENT GOVERNANCE
}

\author{
Sander Happaerts
}

\begin{abstract}
Subnational governments (such as provinces, states or regions) are largely ignored in international policy documents on sustainable development, and they are not recognized in multilateral decision-making. Nevertheless, many subnational governments have launched sustainable development policies. This paper examines to which extent they take global sustainable development governance into account when doing so. A theoretical framework is used that builds upon the literature of policy convergence. Two mechanisms of policy convergence are studied (international harmonization and transnational communication) and their theoretical insights are complemented with insights from regime theory and globalization scholars. That framework is then applied on a comparative policy analysis of five subnational governments: North Holland (the Netherlands), North Rhine-Westphalia (Germany), Wallonia (Belgium), Flanders (Belgium) and Quebec (Canada). The findings show that subnational governments with a distinct territorial identity react differently on international impulses than other subnational governments. Flanders and Quebec, the cases that have such an identity, follow the rules and decisionmaking procedures of the international sustainable development regime, and they translate the norms and principles into their policies. The paper also finds that the influence of international policies is determined by the active participation of subnational governments in multilateral decision-making. Finally, it is argued that the legitimacy pressures exerted by international organizations on lower-level governments to adopt certain policies, have a varying impact on subnational governments which depends on their domestic context.
\end{abstract}

\section{KEY WORDS}

Global Governance, Identity Politics, International Regimes, Legitimacy Pressures, Policy Convergence, Subnational Governments, Sustainable Development

\section{AUTHOR}

Sander Happaerts is a research fellow and $\mathrm{PhD}$ candidate at the Institute for International and European Policy and a member of the Leuven Centre for Global Governance Studies.

\section{AdDRESS FOR CORRESPONDENCE}

sander.happaerts@soc.kuleuven.be

(C) 2011 by Sander Happaert. All rights reserved. No portion of this paper may be reproduced without permission of the authors.

Working papers are research materials circulated by their authors for purposes of information and critical discussion. They have not necessarily undergone formal peer review. 


\section{CONTENTS}

1. INTRODUCTION: SUBNATIONAL GOVERNMENTS AND SUSTAINABLE DEVELOPMENT

2. THEORIZING INTERNATIONAL INFLUENCE ON SUBNATIONAL GOVERNMENTS

3. Global sustainable deVelopment Governance 8

4. Presentation of the cases and methodology 11

$\begin{array}{ll}\text { 5. RESULTS OF THE ANALYSIS } & 13\end{array}$

5.1 INTERNATIONAL HARMONIZATION AND COMPLIANCE WITH THE 13 SUSTAINABLE DEVELOPMENT REGIME

5.2 INTERNATIONAL NORMATIVE DISCOURSE AND THE PROMOTION OF 16 POLICY MODELS

6. COMPARATIVE PATTERNS AND CONCLUSIONS 


\section{INTRODUCTION: SUBNATIONAL GOVERNMENTS AND SUSTAINABLE DEVELOPMENT}

The publication of the Brundtland Report in 1987 put the concept of sustainable development on the global political agenda. Defining sustainable development as "development that meets the needs of the present without compromising the ability of future generations to meet their own needs" (WCED 1987: 43), the Brundtland Commission advanced the view that environmental challenges lie at the heart of economic development, social problems and even international peace and security. Sustainable development was presented as a universal political project, a joint challenge to safeguard the common future of the North and the South. Since 1987, the policy implications for sustainable development have been defined at the global level, most importantly at the 1992 'Earth Summit' in Rio de Janeiro. Sustainable development is considered by scholars as an 'outside-in' policy, i.e. a policy of which the main elements are internationally decided and subsequently need to be 'brought home' by lower-level governments (Lafferty 2004: 17; O'Toole 2004: 34). While global summits and multilateral institutions set goals and directions to steer global sustainable development, lower levels of governance take the lead in terms of concrete implementation and context-specific solutions. That needs to happen with a concern for vertical policy integration, to assure the coherence of various policy efforts at different levels of governance (Bruyninckx 2006: 269).

Although all levels of governance have their role to play, the main international policy documents especially address sovereign national governments to take the key steps. That is not surprising, in the view that national governments are the main actors negotiating international action and that, as gatekeepers, they can decide how to organize cooperation with lower levels of governance within their own borders. National governments are thus requested to implement the international decisions regarding sustainable development policies. In addition, a key role has been attributed to cities. Praising their closeness to citizens and societal groups, cities were asked to develop Local Agenda 21s to make sustainable development a concrete reality in local communities (UNCED 1992a: §28.2a). The international policy discourse, however, remains silent on the role of subnational entities, understood here as "coherent territorial entit[ies] situated between local and national levels with a capacity for authoritative decision-making" (Marks et al. 2008: 113), which entails entities such as provinces, states or regions. ${ }^{1}$ Nevertheless, many subnational governments have initiated sustainable development policies in recent years and they are becoming increasingly active at the international level, claiming a role as legitimate actors in multilateral decision-making on sustainable development. In the domain of governance for sustainable development, there is a research gap with regard to the efforts of subnational governments. That is remarkable, since they constitute a vital link in the multi-level governance of sustainable development. In many countries, subnational governments are responsible for a large part of the implementation of policies (OECD 2002a: 19). Moreover, the responsibility for formulating policies in some domains often lies not at the national, but at the subnational level. Therefore, many problems related to sustainable development (e.g. with regard to energy, transport, spatial planning) can sometimes only be

\footnotetext{
${ }^{1}$ Although some authors refer to subnational governments as 'regions', I reserve the term 'region(al)' to denote the level of governance above the nation-state (e.g. the EU), as is common in international relations theory and the literature on global governance.
} 
handled by subnational governments, depending on the distribution of powers within countries.

This paper addresses a specific question with regard to governance for sustainable development at the subnational level. Considering that sustainable development is an outside-in policy, but that international policy documents remain silent on subnational governments, the paper studies whether those subnational governments respond to global sustainable development governance and how their policies take international requirements into account. The question refers to a general research interest with regard to the influence of international developments on subnational sustainable development policies. Sustainable development is approached as a meta-policy, "a policy designed to guide the development of numerous more specific policies" (O'Toole 2004: 38). I consider how subnational governments interpret sustainable development and translate it into their policies, but I do not analyze the content of the specific policy domains that are considered as elements of sustainable development (such as climate change or biodiversity).

In the following section, a theoretical approach is presented to frame the research question. Subsequently, I provide a description of what is meant by 'global sustainable development governance'. I then proceed to the methodology and the results of a comparative policy analysis of five subnational governments. Conclusions are presented in a final section.

\section{THEORIZING INTERNATIONAL INFLUENCE ON SUBNATIONAL GOVERNMENTS}

The influence of international governance processes on subnational governments has rarely been studied (cf Fleurke and Willemse 2006: 88). Recently, scholars are analyzing the impact of specific EU policies, or of 'Europeanization' in general, on subnational governments (Carter and Pasquier 2010). Not much is known, however, about the impact of global policies, nor about the topic of sustainable development. As a consequence, the theoretical framing of the research question demands an approach that draws on different relevant traditions. In what follows, a theoretical framework is developed based on the policy convergence literature, complemented by insights from regime theory and from the globalization literature. Subsequently, I discuss how those theoretical contributions are applicable to subnational governments.

Policy convergence scholars study how policies of different governments become increasingly similar over time (Knill 2005: 768). Using a comparative policy perspective, studies of policy convergence thus offer causal explanations on the similarities between different policies. A significant part of those causal mechanisms relate to the international policy environment (Bennett 1988: 420; Holzinger and Knill 2008: 404). The literature on policy convergence is a research strand pertaining to the tradition of policy transfer ${ }^{2}$, which is situated at the crossroads of comparative policy analysis and of international relations (Brans et al. 2003: 115, 128-129).

\footnotetext{
2 Brans et al. (2003: 129) employ 'policy transfer' as a conceptual umbrella to encompass policy convergence, policy diffusion, policy learning and related research traditions. The concept of policy transfer was introduced in comparative policy analysis through international relations theory, where scholars studied the activities of policy-makers in transnational policy arenas (Brans et al. 2003: 115).
} 
Among the international mechanisms of policy convergence, two are particularly interesting here, i.e. international harmonization and transnational communication. ${ }^{3}$

First, policy convergence through international harmonization commonly refers to the compliance by national governments with legally binding international commitments (Holzinger and Knill 2005: 781). In the policy convergence literature, this mechanism is thus applied on hard law-defined as "legally binding obligations that are precise (or can be made precise through adjudication or the issuance of detailed regulations) and that delegate authority for interpreting or implementing the law" (Abbott and Snidal 2000: 421). Based on the assumption that governments dutifully implement international legal requirements, international harmonization implies the increasing policy similarity of those governments that are members of the same international institutions, or that have acceded to the same international treaties (Holzinger et al. 2008: 557).

Second, transnational communication, a term coined by Holzinger and Knill (2005: 782-783), describes a set of mechanisms that presuppose nothing but information exchange and communication with other governments or international organizations to generate policy convergence, rather than legal requirements. A particular mechanism of transnational communication is described as 'the promotion of policy models by international organizations' (Holzinger and Knill 2005: 785). ${ }^{4}$ In order to accelerate the diffusion of certain innovations, international organizations invest in the dissemination of guidelines, information on best practices, evaluations of existing policies, benchmarks or propositions on general goals. In doing so, they function as mediators of policy convergence without legal pressure (Holzinger and Knill 2008: 405; Tews et al. 2003: 573). The primary incentive of policy transfer through this mechanism consists of the legitimacy pressures exerted by international organizations (Holzinger and Knill 2005: 785). That means that compliance is not driven by coercion or legal pressure, but that it happens voluntarily because of the perception of quality on the part of the emitting institution, or of the content of the message (Franck 1990: 26).

In order to strengthen the theoretical framework, the contributions of the policy convergence literature are complemented with insights of other traditions that describe similar phenomena. An important link is made here between policy convergence through international harmonization and the effects of international regimes. Bennett (1991: 225) explains that the analysis of international harmonization is at the intersection of comparative policy analysis and regime theory. International regimes are defined as "sets of implicit or explicit principles, norms, rules, and decision-making procedures around which actors' expectations

\footnotetext{
${ }^{3}$ Other international mechanisms of policy convergence are imposition (i.e. policies are enforced upon governments by third parties) and regulatory competition (i.e. mutual adjustment of trade-related policies through the economic integration of markets) (Bennett 1988: 420; Knill 2005: 770). They are not further considered here.

${ }^{4}$ Transnational communication includes two other mechanisms of policy convergence, i.e. 'policy copying' (governments learning from the experiences of others) and 'networking activities' (governments establishing transnational networks for information-sharing). Those are not further considered in this paper, because they do not specifically focus on the top-down influence from the international to the subnational level of governance.
} 
converge in a given area of international relations" (Krasner 1982: 186). ${ }^{5}$ What regime theory contributes to the policy convergence literature, is that it reveals that harmonization processes are not limited to hard law. Rather, regimes encompass all formal and informal arrangements that exist between states in a certain issue area of international politics (Bennett 1991: 226), including softer forms of law. Soft law is defined as the "rules of conduct which in principle have no legally binding force but which nevertheless may have practical effects" (Snyder, cited in Trubek et al. 2005: 1). Regime analysts look at how principles, norms, rules or procedures associated with international organizations influence the behaviour of lower-level governments (Barkin 2006: 36).

Finally, insights from scholars of globalization are used to strengthen the mechanisms of transnational communication. There is a strong relation between the promotion of policy models by international organizations and what Bernstein and Cashore (2000) refer to as 'international normative discourse'. Concerned with the impact of globalization on public policies, they describe how international organizations embody certain norms of appropriate behaviour, and develop a discourse around those norms that is explicitly intended to influence domestic practices (Bernstein and Cashore 2000: 81-82). If the norms become internationally institutionalized, they can frame domestic policy discourses (Bernstein and Cashore 2000: 82; Risse-Kappen 1996: 69). Norms can influence policies even when they are not accompanied by binding rules. As a consequence, international organizations that have low enforcement power or that are weak in providing binding rules, can still have significant influencing power through normative discourse (Bernstein and Cashore 2000: 83). The influence operates primarily through communication and moral suasion (Bernstein and Cashore 2000: 82-82). It thus corresponds with the legitimacy pressures described by the concept of transnational communication. Governments comply with the international normative discourse out of concern for their reputation. That is why especially governments that aspire to belong to a certain international community are susceptible to it (Bernstein and Cashore 2000: 81-82; Keck and Sikkink 198: 29).

\footnotetext{
${ }^{5}$ Principles are defined as "beliefs of fact, causation, and rectitude", norms are "standards of behavior defined in terms of rights and obligations", rules are "specific prescriptions or proscriptions for action" and decision-making procedures are "prevailing practices for making and implementing collective choice" (Krasner 1982: 186). In the next section, examples of those elements are given in the context of the international sustainable development regime.
} 
Table 1 summarizes the combined insights of these theoretical perspectives.

\begin{tabular}{|l|l|l|}
$\begin{array}{l}\text { international mechanisms } \\
\text { of policy convergence }\end{array}$ & $\begin{array}{l}\text { other theoretical } \\
\text { insights }\end{array}$ & \multicolumn{2}{|l|}{ influence mechanisms } \\
\hline $\begin{array}{l}\text { policy convergence through } \\
\text { international } \\
\text { harmonization }\end{array}$ & $\begin{array}{l}\text { international } \\
\text { regimes }\end{array}$ & $\begin{array}{l}\text { lompliance with legally binding } \\
\text { rules, but also with 'soft' } \\
\text { principles, norms and procedures } \\
\text { associated with IOs and regimes }\end{array}$ \\
\hline $\begin{array}{l}\text { policy convergence through } \\
\text { transnational } \\
\text { communication: } \\
\text { promotion of policy } \\
\text { models by IOs }\end{array}$ & $\begin{array}{l}\text { international } \\
\text { normative } \\
\text { discourse }\end{array}$ & $\begin{array}{l}\text { legitimacy pressures exerted by } \\
\text { conform to a certain behaviour }\end{array}$ \\
\hline
\end{tabular}

Table 1 Combined theoretical framework ( $\mathrm{IO}=$ international organization)

The first influence mechanism focuses on the enforcement of rules and on the influence of international regimes. The logic behind it is that international cooperation between governments results in principles, norms, rules and procedures, which can both have a hard-law or a soft-law character. They can then have an influence on the policies of the governments that engaged in the international cooperation. The second influence mechanism departs not from imposed influence resulting from international cooperation, but rather from the initiatives of international organizations to present certain approaches as 'ideal' policies, and promote them through persuasive communication. Although the distinction is maintained in the analysis, it must be emphasized here that the two mechanisms serve a single research aim, i.e. the question whether subnational governments respond to global sustainable development governance.

It is expected that the described influence mechanisms are also of relevance in the case of subnational governments, even though the theoretical literature largely ignores them. First, with regard to international harmonization through legally binding rules, it is only logical that subnational governments are influenced by it, in those countries where they are responsible for the implementation of certain international policies. In several countries indeed, much of the implementation of international agreements is done at the subnational level, although subnational governments are mostly not the ones formally committing to those agreements. Especially in the context of the EU, scholars have studied the implementation or transposition of regulations and directives by subnational governments (e.g. Borghetto and Franchino 2010). In the case of soft law and the broader impact of international regimes, research with regard to subnational governments is in a much more exploratory stadium. Nevertheless, I expect that subnational governments can also be influenced by 'softer' aspects of international regimes, especially those that in one way or another are involved in or touched by activities related to international regimes.

Second, with regard to transnational communication and the promotion of policy models by international organizations, it is clear that the relevant actions of those organizations are above all targeted at national governments. As a consequence, the 
legitimacy pressures are mainly exerted upon national governments too. However, also here a certain impact on subnational governments can be expected. As legitimacy pressures are especially felt by governments that aspire to belong to a certain international community (cf supra), I hypothesize that subnational entities with a proper territorial identity can be susceptible to them. In the field of comparative regionalism and federalism, scholars often invoke the presence of territorial identities to explain certain activities and policies of subnational governments, notably with regard to their external policies (Keating 1999: 5, 13; Lecours 2002: 97-100, 104). That phenomenon is referred to as 'identity politics'. ${ }^{6}$ Subnational entities that have a proper territorial identity, and that are keen to apply identity politics to construct or reinforce that identity, frequently manifest the aspiration to belong to certain international communities. That is why I expect that legitimacy pressures exerted by international organizations have a potential impact on them. Such identity politics are more likely to be found in cases where subnational entities have their own language and culture and in those with aspirations for higher autonomy (Keating 1999: 5; Lecours 2002: 100-101; Palermo and Santini 2004: 20). In very extreme cases, subnational governments apply identity politics to escape from central governments' control and to acquire state-like qualities, or even to be recognized as a 'nation' altogether. In those cases, it could be argued that a subnational government complies with the rules of the 'community of nation-states' in order to manifest its membership in that community and validate its statehood (cf Franck 1990: 8). ${ }^{7}$

\section{GLOBAL SUSTAINABLE DEVELOPMENT GOVERNANCE}

This section applies the two influence mechanisms developed above to sustainable development. ${ }^{8}$ Attention is paid to two international organizations at the global level, i.e. the UN and the OECD, and also to the EU, which has always been a promoter of global sustainable development (Van den Brande 2011a). ${ }^{9}$ However, although the main focus in the literature is on international organizations as such, my discussion starts with the global sustainable development summits. I argue that those summits, as the main political milestones for sustainable development, play an important role in both influence mechanisms.

\footnotetext{
${ }^{6}$ According to Hill and Wilson, identity politics indicate processes, actions or discourses whereby various entities (political, economic or social) attempt to mould collective identities into fixed frames for understanding political action (Hill and Wilson 2003: 2). Paquin talks of identity paradiplomacy, "a paradiplomacy or a subnational foreign policy of which the fundamental objective is the reinforcement or the construction of the nation in the framework of a multinational country" (Paquin 2003: 622, personal translation).

${ }^{7}$ Franck compares the norms of international institutions with the house rules of a club: "the desire to be a member of the club [...] is the ultimate motivator of conformist behaviour" (Franck 1990: 38).

${ }^{8}$ Parts of this section are based on earlier research by Happaerts and Van den Brande (2010: 9-13). The sustainable development debate within the UN and the OECD is also discussed by Van den Brande (2010).

9 Although I consider the UN, the OECD and the EU to be the three most relevant international organizations in this context (cf Van den Brande et al. 2011: 71), others can be important as well, although they are often overlooked by comparative policy analysts, regime analysts and sustainable development scholars. The International Organization of La Francophonie (OIF) is a case in point. Largely unknown in the non-francophone world, the OIF is active on a wide range of issues in Frenchspeaking nations around the globe. For instance, it promotes sustainable development among its 56 member states through the Institut de l'énergie et de l'environnement (IEPF). Among other things, the IEPF conducts peer reviews of national sustainable development strategies (SDSs) (IEPF 2010).
} 
After the publication of the Brundtland Report, the global debate was driven by largescale global summits organized under the auspices of the UN, i.e. the Rio Summit (the UN Conference on Environment and Development in 1992) and its successor in Johannesburg (the World Summit on Sustainable Development in 2002). Such summits usually attract a large number of governmental delegations, including administrative and political officials, sometimes even heads of state, and they are attended and observed by a broad range of interest groups (cf Death 2011: 2). Global summits generate publicity and political momentum for policy issues. They also shape the global sustainable development regime and could thus contribute to international harmonization. The output of global summits usually consists of solemn political declarations (e.g. Rio Declaration, Johannesburg Declaration) and policyoriented actions plans (e.g. Agenda 21, Johannesburg Plan of Implementation). Those are not binding treaties, but they do formulate principles, norms and rules that governments ought to transpose into their policies. For instance, the Rio Declaration defines 27 policy principles for sustainable development, such as participation or precaution (UNCED 1992b). In order to integrate such principles in decision-making, Agenda 21 formulates the rule to develop national sustainable development strategies (SDSs) (UNCED 1992a: §8.7). The harmonization effect of global summits is implied by the observation that political action on sustainable development peaked at the time of the Rio and Johannesburg Summits (Quental et al. 2011). That suggests that the global sustainable development regime triggers the establishment of sustainable development policies. As a final remark, subnational governments have contributed to the sustainable development regime as well. During a side-event at the Johannesburg Summit, 23 subnational governments from different continents negotiated and signed the Gauteng Declaration (named after the South African province of which Johannesburg is the capital), which included the rule to develop subnational SDSs (The Gauteng Declaration 2002: $§ 7$ ). ${ }^{10}$

Also in the promotion of policy models, global summits and their outputs are important driving forces. For instance, Agenda 21 generated widespread support for the view that sustainable development entails three pillars: economic, social and environmental (UNCED 1992a: §8.41). Furthermore, Agenda 21 issues concrete recommendations on a wide range of mechanisms to implement sustainable development, i.e. financial mechanisms, international cooperation and capacitybuilding, technology transfer, science, education, information for decision-making and international law (UNCED 1992a: §33-40). While several of those mechanisms are intended for strengthening the global governance architecture of sustainable development, other recommendation are made for lower-level governments, for instance the development of indicators for sustainable development (UNCED 1992a: $\S 40.4)$.

Turning now to international organizations in the strict sense, the Commission on Sustainable Development (CSD) is mandated to oversee the implementation of the Rio and Johannesburg commitments within the UN system (Van den Brande et al. 2011: 72). Although it is a soft-law forum (Cordonier Segger 2004: 68), the CSD has

\footnotetext{
${ }^{10}$ The Gauteng event also laid the foundation of the Network of Regional Governments for Sustainable Development (nrg4SD), which aims to represent subnational governments in multilateral decisionmaking on sustainable development, and to promote cooperation and information-sharing among its members (Happaerts et al. 2010a).
} 
the potential to generate harmonization effects. From the point of view of regime theory, its decision-making procedures might impact on the policies of member states. Andresen (2007: 325-326) explains how the CSD attaches large importance to the reporting duties of governments, and how the large majority follows that procedure, although they are not legally obliged to do so. Those national reports on sustainable development policies have reportedly contributed to a strengthened coordination among governments (Andresen 2007: 326). The CSD also plays a meaningful role with regard to the promotion of policy models. It has the task of providing policy recommendations and diffusing best practices in order to guide governments in their pursuit of sustainable development (UNDESA 2008a). For instance, the CSD has done authoritative work in promoting sustainable development indicators (UNDESA 2008b).

Within the group of industrialized countries, the OECD is not expected to contribute to international harmonization, but it is active in the promotion of policy models. The OECD aims to share best practices on sustainable development and it publishes various recommendations, guidelines and background notes on the topic (e.g. OECD 2001, 2002b; OECD and UNDP 2002). The OECD is a prime example of an "ideasmongering institution" (Rose 1993: 69) and is renowned to have considerable normative and ideational power (Marcussen 2004a, 2004b).

In the context of the EU, harmonization effects of regimes have since long been observed (Bennett 1991: 227). Kraemer et al. (2003: 13-14) and von Homeyer (2009: 18-24) describe the EU's sustainable development regime. Introduced in the 1997 Amsterdam Treaty, ${ }^{11}$ the regime is now dominated by the EU's proper Sustainable Development Strategy (EUSDS). The EUSDS, formulated first in 2001, formulates key issue areas for action on sustainable development within the EU. ${ }^{12}$ It also aspires to increase the vertical policy integration of sustainable development between the EU level and the member states (Steurer and Hametner 2010). The EUSDS was renewed in 2006, and member states are currently negotiating a second renewal. The EU's sustainable development regime has a legally nonbinding character. It is mostly based on non-legislative measures, such as Commission communications and Council conclusions, and on cooperation procedures similar to the Open Method of Coordination (Kraemer et al. 2003: 14; Spangenberg 2010: 131; von Homeyer 2009: 19). That is not to say, however, that it cannot permeate EU hard law, such as regulations or directives-but "even legislative measures associated with the sustainable development regime often do not impose legally binding obligations in all important respects" (von Homeyer 2009: 20). Nor does it mean that it does not contain rules. For instance, the EUSDS asks

\footnotetext{
${ }^{11}$ Art. 6 of the Amsterdam Treaty (now art. 11 of the Treaty on the Functioning of the European Union), states that "[e]nvironmental protection requirements must be integrated into the definition and implementation of the Union's policies and activities, in particular with a view to promoting sustainable development" (European Union 2010: §11).

${ }^{12}$ The 2001 EUSDS proposes six priority fields: combating poverty and social exclusion; dealing with the economic and social implication of an ageing society; limiting climate change and increase use of clean energy; addressing threats to public health; managing natural resources more responsibly; and improving the transport system and land-use management (European Commission 2002). The renewed EUSDS in 2006 formulates seven key challenges: climate change and clean energy; sustainable transport; sustainable consumption and production; conservation and management of natural resources; public health; social inclusion, demography and migration; and global poverty and sustainable development challenges (Council of the European Union 2006).
} 
member states to complete a national SDS (Council of the EU 2006: §40). Furthermore, harmonization is facilitated through the procedures of the regime, which operates through reporting, monitoring and evaluation (Kraemer et al. 2003: 14). For instance, the European Commission supports a system of peer reviews of national SDSs by other member states (Spangenberg 2010).

The EU is also active in the promotion of policy models for sustainable development. Its activities on sustainable development rely to a large extent on legitimacy pressures (von Homeyer 2002: 295). To promote sustainable development, the EU produces guidelines, benchmarks and performance indicators (Kraemer et al. 2003: 14). Those outputs have a strong normative element (von Homeyer 2009: 22), meant to influence the sustainable development policies of member states.

\section{Presentation of the cases and methodology}

The paper applies the theoretical framework to a comparative case study analysis of five subnational governments: North Holland (the Netherlands), North RhineWestphalia (Germany), Wallonia (Belgium), Flanders (Belgium) and Quebec (Canada). The analysis is situated in a $\mathrm{PhD}$ project which engages in a structured and focused comparison of those five cases (cf George and Bennett 2005: 67-70), using a qualitative research method. ${ }^{13}$ The data was gathered through an extensive study of governmental documents, through 90 semi-structured interviews with policy officials and stakeholders in the five cases, and through secondary literature.

The five cases were selected from highly industrialized, democratic societies. Four of them are from different types of federal countries, while North Holland forms part of a decentralized, unitary state. As they have varying constitutional contexts, the cases vary with regard to their degree of autonomy. Measured by their degree of self-rule i.e. the autonomy that they have with respect to policy-making within their own jurisdictions (Marks et al. 2008: 115) ${ }^{14}$-North Holland has the lowest autonomy with a score of 8/15, while Quebec has the maximum score of 15/15 (see Table 2). Moreover, it is interesting that one of the five cases, i.e. Quebec, does not operate in an EU context, to assess the importance of the EU in mechanisms of international harmonization and transnational communication. Some background figures of the cases are given in Table 2 below. It also summarizes the main elements of the sustainable development policy of each case.

\footnotetext{
${ }^{13}$ Besides international factors, the PhD retains other explanatory factors for the analysis, i.e. degree of autonomy, political context and socioeconomic conditions. It studies the influence of those factors on the sustainable development policies of subnational governments, declined into 'policy framing', 'policy goals' and 'policy instruments'. More information about the research, its methodology or the selection of cases can be obtained from the author. The research is funded by the Flemish Policy Research Centre for Sustainable Development (www.steunpuntdo.be).

${ }_{14}$ Self-rule is measured by the Regional Authority Index, developed by Hooghe et al. (2008b). It contains four indicators: 'institutional depth', 'policy scope', 'fiscal autonomy' and 'representation' (Hooghe et al. 2008a: 124-131). The aggregation results in a score between 0 and 15, which gives an indication of the independence of subnational governments vis-à-vis the national level and on the scope of their competences. The importance of the degree of self-rule for the sustainable development policies of subnational governments is described by Happaerts (2010a).
} 


\begin{tabular}{|c|c|c|c|c|c|}
\hline & $\begin{array}{l}\text { North } \\
\text { Holland }\end{array}$ & $\begin{array}{l}\text { North } \\
\text { Rhine- } \\
\text { Westphalia }\end{array}$ & Wallonia & Flanders & Quebec \\
\hline country & $\begin{array}{l}\text { the } \\
\text { Netherlands }\end{array}$ & Germany & Belgium & Belgium & Canada \\
\hline capital & Haarlem & Düsseldorf & Namur & Brussels & $\begin{array}{l}\text { Quebec } \\
\text { City }\end{array}$ \\
\hline population $^{15}$ & $2,626,163$ & $17,996,621$ & $3,456,775$ & $6,161,600$ & $7,716,500$ \\
\hline GDP/cap. ${ }^{16}$ & 37,000 EUR & 27,100 EUR & 20,800 EUR & 28,700 EUR & 23,790 EUR \\
\hline self-rule & $8 / 15$ & $12 / 15$ & $13 / 15$ & $13 / 15$ & $15 / 15$ \\
\hline $\begin{array}{l}\text { main } \\
\text { elements of } \\
\text { SD policy }\end{array}$ & $\begin{array}{l}\text { SD in } \\
\text { coalition } \\
\text { agreement } \\
\text { (2007), } \\
\text { Agenda } \\
\text { Sustainability } \\
\text { (2010) }\end{array}$ & $\begin{array}{l}\text { Agenda } 21 \\
N R W(2000- \\
2005)\end{array}$ & $\begin{array}{l}\text { failed } \\
\text { attempts to } \\
\text { establish } \\
\text { SD policy } \\
\text { (1994- } \\
\text { 2008), } \\
\text { Marshall } \\
\text { Plan } \\
\text { 2.Green } \\
\text { (2009) }\end{array}$ & $\begin{array}{l}\text { SD policy } \\
\text { since 2004, } \\
\text { SDS } \\
\text { (2006), SD } \\
\text { Act (2008), } \\
\text { revised } \\
\text { SDS } \\
\text { (expected } \\
\text { 2011) }\end{array}$ & $\begin{array}{l}\text { SD policy } \\
\text { since 2004, } \\
\text { SD Act } \\
(2006), \\
\text { SDS } \\
(2007)\end{array}$ \\
\hline
\end{tabular}

Table 2 Key characteristics of the cases (SD = sustainable development)

In the Dutch province of North Holland, sustainable development was included as a general goal in the coalition agreement of the executive council that took office in 2007 (Provincie Noord-Holland 2007: 3). The provincial administration subsequently developed the Agenda Sustainability in 2010, which expressed the province's vision on sustainable development, and its intention to advance on a key set of policy issues, such as sustainable agriculture and sustainable mobility. In North RhineWestphalia, a coalition of Socialists and Greens established the state-wide Agenda 21 project called Agenda $21 \mathrm{NRW}$, to institutionalize sustainable development. The process, conducted between 2000 and 2005, was based on an extensive consultation of citizens and stakeholder groups, aimed at making sustainable development concrete through a series of projects. It resulted in concrete recommendations for a subsequent SDS (MUNLV 2005), but those were never enacted by the coalition of Christian Democrats and Liberals that came into power in 2005. In Wallonia, several failed attempts have been undertaken to institutionalize sustainable development between 1994 and 2008 (cf Happaerts 2010b). For instance, a Walloon SDS has been developed in an effort lead by the Environment Minister, but it was never approved by the government. In 2009, sustainable development became one of the transversal objectives of the Marshall Plan 2.Green, Wallonia's high-profile economic strategy. Flanders adopted an SDS in 2006 (Vlaamse Regering 2006). Since then, a small unit within the administration of the Prime Minister-who was given the responsibility of sustainable development in 2004-oversees the coordination between departments on a series of sustainable development projects (e.g. sustainable housing and living). The Flemish sustainable

\footnotetext{
${ }^{15}$ Total population in 2008 (Eurostat 2011; ISQ 2008a: 15).

${ }^{16}$ Gross domestic product per capita in 2005 at current market prices in EUR (Eurostat 2011; ISQ 2008b: 36; 2010). The value for Quebec (35,887 CAD) was converted at 2005 average exchange rates.
} 
development policy was given legal continuity by a Sustainable Development Act in 2008 (Vlaams Parlement 2008). In Quebec, finally, sustainable development has been on the agenda since 1988, when the government financed the French version of the Brundtland Report. However, it was not until 2003 that a comprehensive sustainable development policy was carried out. Its main elements are the Sustainable Development Act (Assemblée Nationale 2006), the creation of the Sustainable Development Commissioner within the office of the Auditor General of Quebec, and the government's SDS (Gouvernement du Québec 2007).

Due to space constraints, the analysis of the cases cannot be presented in full detail in this paper. The following section is therefore limited to the main results of the comparative analysis. It presents and illustrates the findings of the application of the two mechanisms of international influence developed above. First, the different elements of the international sustainable development regime are studied. Second, I focus on the impact of legitimacy pressures and the promotion of policy models by international organizations.

\section{RESULtS OF THE ANALYSIS}

\subsection{INTERNATIONAL HARMONIZATION AND COMPLIANCE WITH THE SUSTAINABLE DEVELOPMENT REGIME}

In assessing whether subnational governments respond to global sustainable development governance, it is first of all pertinent to evaluate whether the international regime triggered the institutionalization of a sustainable development policy at the subnational level. In other words: is the presence of a sustainable development policy the result of the international regime? Subsequently, the influence of rules, procedures, principles and norms related to the regime is illustrated.

The trigger function of the international regime was most direct in the case of Flanders. The first step of a Flemish sustainable development policy was an administrative working group on sustainable development, launched by Flemish officials in 2003 and meant in part to co-ordinate international activities. The initiative was a direct consequence of the Johannesburg Summit, where a large Flemish delegation was present. Besides participating in the Belgian delegation at the Summit, the Flemish Environment Minister co-organized the Gauteng event. In addition, the Flemish government had been actively involved in the Belgian Presidency of the EU in the second half of 2001, when the Johannesburg Summit was prepared and the EU member states were negotiating the first EUSDS. ${ }^{17}$ In the cases of Quebec and North Rhine-Westphalia, international developments also

\footnotetext{
${ }^{17}$ Within the EU, the negotiations on Johannesburg and on the EUSDS took place in the Environment Council. In Belgium, subnational Environment ministers were permitted to assist the federal Environment minister in the Council at that time. (Since 2003, Belgium is represented by a subnational Environment minister, assisted by the federal minister.) During the 2001 Presidency, as the federal minister already occupied the Presidency seat and represented Belgium as the Council Presidency, the subnational minister-in this case it was the Flemish minister, according to a rotation system-occupied the Belgian seat and represented Belgium as an EU member state. Flanders was thus at the front row when Johannesburg and the EUSDS were discussed (Happaerts and Van den Brande 2010: 21).
} 
played a role, but their impact was rather indirect. In Quebec, several structures were established as a response to the activities of the Brundtland Commission and the Rio Summit (including the Round Table on Environment and Economy, a sustainable development unit within the Environment Ministry, and the Interministerial Committee on Sustainable Development). Although those initiatives were not accompanied by a sustainable development policy at the time, they were important foundations when Quebec's Liberal party in 2003 decided to institutionalize sustainable development after its return to power. ${ }^{18}$ In North Rhine-Westphalia, the establishment of a state-wide Agenda 21 was fuelled by bottom-up initiatives in the aftermath of the Rio Summit, most importantly the numerous Local Agenda 21s in North Rhine-Westphalian municipalities (cf Kern et al. 2007). The situation is different in the cases of Wallonia and North Holland, where international factors played no role, and national factors were sometimes more significant in triggering sustainable development initiatives. The intention to produce a Walloon SDS was a direct consequence of an initiative by the Belgian federal State Secretary for Sustainable Development to negotiate a national SDS (encompassing both the federal and the subnational governments). Wallonia read the initiative as a formal request to develop a Walloon SDS (while the Flemish government did not share that interpretation). ${ }^{19}$ In North Holland, the development of the Agenda Sustainability happened autonomously from international developments, but it was in part stimulated by a national initiative to develop a provincial sustainability monitor, to benchmark the provinces' performances with regard to sustainable development.

One of the strongest rules of the global sustainable development regime concerns the development of an SDS. Some subnational governments duly took note of that rule. Flanders and Quebec explicitly invoke international commitments in the justification of their SDSs. Flanders frequently emphasizes that it feels bound by the commitments made in Johannesburg, but also by the Gauteng Declaration and the EUSDS (Leterme 2004: 6; Vlaamse Regering 2006: 14, 16, 31). As no other justifications are given, those international commitments appear as the only reason why a Flemish SDS was issued, thus giving a very large importance to the international commitments. Also in the case of Quebec, the UN commitments to develop a 'national' SDS are explicitly invoked (Gouvernement du Québec 2004: 12). After its participation at the Rio Summit, the government of Quebec formally committed itself to the principles and goals of the Rio Declaration and Agenda 21, and it feels bound by the engagements made in Johannesburg (Gouvernement du Québec 2009; 2010: 4). In North Rhine-Westphalia, the analysis suggests that, although Rio's Agenda 21 was considered as a role model for the state-wide initiative (SPD and Die Grünen 2000: 21), the government did not feel directly addressed by the international regime, but rather felt the obligation to act on sustainable development because of bottom-up initiatives, and because the German federal government failed to do so (Landesregierung NRW 2002: 6; Landtag NRW 1998). While the project was first launched as an SDS (Landtag NRW 2002: 7396),

\footnotetext{
${ }^{18}$ Quebec's new Prime Minister Charest was a former Environment Minister at the federal level. In that capacity, he had been responsible for the follow-up of the Green Plan, which Canada presented as its approach to sustainable development at the Rio Summit (Tarasofsky 2007: 4). Having become Prime Minister of Quebec in 2003, Charest ordered his Environment Minister to launch a similar 'green plan' in Quebec. It is another illustration of the indirect impact of the Rio Summit in the Quebec case.

${ }_{19}$ In contrast, the fact that Wallonia had also signed the Gauteng Declaration at the Johannesburg Summit did not play a role in the Walloon case (Happaerts 2010b: 5).
} 
its status was later weakened, and it was presented as a process resulting in recommendations that needed to lead up to a subsequent SDS (MUNLV 2005). In Wallonia, although the draft text of the Walloon SDS refers to UN, OECD and EU commitments, those were never strong enough to guarantee the government's backing of the project. Subsequently, the Marshall Plan 2.Green did not invoke the international sustainable development regime. North Holland does not feel bound by international commitments on sustainable development. In the context of a debate in the Netherlands on the role of the provinces, and a reduction of their budget, North Holland explicitly stated that it considers international policies and development cooperation as a matter of exclusive national competence, and that the province should focus on its core tasks in the economic and spatial domain.

The international sustainable development regimes also include decision-making procedures, most importantly regarding national reporting. In Belgium, the subnational governments are actively involved in the development of national reports for the CSD and for the EUSDS. While the formulation of national reports is coordinated by the federal government, the subnational governments are asked to provide the input regarding the matters under their competences. That is a consequence of the exclusivity of competences which characterizes Belgian federalism (Happaerts et al. 2011: 6; Swenden and Jans 2006: 886). Interviews show that the contributions of Flanders to those reports are generally more significant than those of Wallonia. Flanders is traditionally much more active in the different national coordination mechanisms on Belgian or international decisionmaking (Happaerts 2010a: 20; Van den Brande 2011b: 13). In the other cases, similar opportunities to take part in national reporting procedures are not present. ${ }^{20}$ Quebec, however, does respond to this procedure related to the global sustainable development regime, by formulating its own reports, independently from the Canadian national reports. It did so, for instance, for the UN General Assembly's special session on 'Rio +5 ' in 1997 and for the Johannesburg Summit in 2002 (Gouvernement du Québec 1996, 2002).

A final point regarding the compliance by subnational governments with the sustainable development regime, is whether other norms and principles of the regime permeate their policies. I analyzed whether they explicitly follow-up on the principles of the Rio Declaration, and whether international goals are taken over in their sustainable development policies. With regard to the policy principles, the loudest response is observed in Quebec. One of the strongest elements of Quebec's Sustainable Development Act is its list of the sixteen sustainable development principles that need to be taken into account in the administration's policy and decision-making (Assemblée Nationale 2006: §I.II.I). The principles are said to be Quebec's response to the 27 principles of the Rio Declaration (Gouvernement $\mathrm{du}$ Québec 2004: 21). Indeed, ten of the sixteen principles bear very close resemblance to the Rio principles (e.g. polluter pays principle, precautionary principle), while six others appear to have been added to accommodate domestic priorities (e.g. subsidiarity, protection of cultural heritage). Moreover, some of the more compelling

\footnotetext{
${ }^{20}$ It is interesting to note, however, that the initiatives of subnational governments are frequently mentioned in the national reports written for the Johannesburg Summit in the federal cases (UNDESA 2002a, 2002b; 2002c), while the Dutch report does not mention the provincial policies (UNDESA 2002d).
} 
principles regarding the environmental dimension were not withheld, such as environmental legislation or environmental impact assessment. The Flemish SDS also states its respect for the Rio principles, and gives principled priority to five of them (equity, common but differentiated responsibilities, participation, the precautionary principle, and horizontal policy integration) (Vlaamse Regering 2006: 35). Such statements are not found in the other cases. With regard to the follow-up of international goals regarding sustainable development, the Flemish case displays the strongest resonance. The Flemish SDS contains an analysis of global and local trends regarding sustainable development, of which international policy goals form an important part. Moreover, the long-term goals of the Flemish SDS frequently refer to international commitments, such as the Kyoto Protocol or European Council conclusions. Similarly, the draft text of the Walloon SDS framed each theme within the global and European commitments to which Wallonia is bound, but the Marshall Plan 2.Green does no such thing. In the policy documents of Quebec and North Rhine-Westphalia, occasional references are made to international policy processes impacting on policy goals (e.g. the UN Decade of Education for Sustainable Development), but it is clear that most of their policy goals are derived from the domestic policy context. North Holland's Agenda Sustainability refers to international policy goals only once, when it mentions the transposition of Natura $2000^{21}$ in the context of biodiversity. It is thus clear that also international policy goals that do not strictly belong to the sustainable development regime, but pertaining to specific issues related to sustainable development, permeate subnational sustainable development policies. In contrast to the sustainable development regime, some of them do have a legally binding character (e.g. Kyoto Protocol). The fact that they permeate subnational sustainable development policies reflects the responsibility of subnational governments in the implementation of certain international commitments.

\subsection{INTERNATIONAL NORMATIVE DISCOURSE AND THE PROMOTION OF POLICY MODELS}

International organizations attempt to promote certain policy models with regard to sustainable development among governments. I assess policy promotion first of all at the level of policy framing: how is sustainable development defined, and how is it interpreted as a policy problem ${ }^{22}$ The definition of sustainable development is clearly influenced by international organizations and events. In all five cases, although differences exist, the applied definition is derived from the Brundtland formulation and the three-pillar vision popularized by the Rio Summit. In the case of North Holland, the mention of the Brundtland definition is the one and only reference to international sustainable development policy. With regard to the broader framing, in the cases of North Rhine-Westphalia and Flanders, the interpretation of sustainable development has a strong dimension of North-South equity attached to it. That dimension has arguably been one of the most prominent elements in the global discourse on sustainable development since the policy concept appeared on the political agenda. The North-South dimension is less strong in Wallonia, weak in

\footnotetext{
${ }^{21}$ Natura 2000 is a network of protected areas in the EU. Its development is based on the Habitats Directive, adopted by the European Parliament in 1992.

${ }_{22}$ Policy framing refers to the process of interpreting a concept and of giving meaning to a problem. It involves the use of available knowledge and information in order to select, name, emphasize or organize certain aspects of a policy problem (Daviter 2007: 654; Schön and Rein 1994: 26).
} 
North Holland, and inexistent in Quebec. A final remark regarding the interpretation of sustainable development is that other international developments can also impact on it. For instance, the framing of sustainable development in North RhineWestphalia was initially focused on the relationship between environmental policy and the business sector. That was a consequence of the fact that the parliamentary debate on sustainable development (between 1997 and 2000) was held in the context of the implementation of EMAS. ${ }^{23}$

Closely related to the policy framing of sustainable development, is the issue of participation. The requirement that a sustainable development policy should be formulated and implemented in consultation with a broad range of governmental and non-governmental stakeholders, is not only one of the Rio principles (UNCED 1992b: $\S 10)$, but more broadly one of the most characteristic elements of the normative behaviour prescribed by international organizations. In North Rhine-Westphalia, the participatory approach was an intrinsic element of the policy framing of sustainable development. Under the influence of the Green party, the Agenda 21 NRW was designed as a broad societal consultation project, involving environmental groups, labour unions, consumer organizations, North-South groups, women, religious organizations, schools, etc. The issue of participation also receives much attention in Quebec and in Flanders, where important elements of the sustainable development policy are carried out in consultation with non-governmental stakeholders.

The promotion of policy models by international organizations also relates to the thematic areas of the policy goals targeted by the sustainable development policies. Sustainable development can indeed entail many things, and governments have to decide which issues are targeted by their policies. The influence of international organizations is strongest in the Flemish case, where the themes of the SDS are faithful copies of the long-term objectives of the first EUSDS. Moreover, many of the concrete projects and recent policy priorities in Flanders reflect international goals, such as education for sustainable development, or sustainable housing and living. Also in Wallonia, although the Marshall Plan 2.Green does not refer to international goals, the themes of the draft Walloon SDS were literally and explicitly copied from the second EUSDS. That influence of the EUSDS is an illustration of the strong normative authority that the EU has in Belgian politics. Unlike in many other EU member states, what the EU says or does is rarely questioned by Belgian politicians (Happaerts et al. 2011: 9). The reason is that it is often easier to agree on EU requirements than to rely on intra-Belgian negotiations (Niestroy 2005: 77, 87). In choosing the themes of their sustainable development policies, Quebec and North Rhine-Westphalia do not invoke international policy documents, yet all of the themes they elaborate are developed by Agenda 21 and/or the EUSDS. North Holland justifies the choice of its themes by its scope of competences. As its low degree of self-rule shows (see Table 2), that scope of competences is the most limited of all five cases. North Holland's sustainable development policy therefore focuses on a

\footnotetext{
${ }^{23}$ Developed by the European Commission, the EU Eco-Management and Audit Scheme (EMAS) is a label attributed to companies that evaluate and improve their environmental performance. In Germany, the government is traditionally proactive in facilitating the adoption of such certifications by its companies. In several German states, the introduction of EMAS triggered agreements between the government and business associations, which in turn were driving forces for the institutionalization of sustainable development (Jänicke et al. 2001: 18-19). The most prominent example is Bavaria's Environmental Pact (Jörgensen 2002: 21).
} 
few clearly delineated issues only, such as sustainable housing and sustainable business parks. The comparison of themes across cases shows that the most widely diffused themes are the 'usual suspects' such as climate change, transport, social policy, or education for sustainable development, among others. However, although the thematic areas of the policy goals often reflect international policy documents, the analysis suggests that the concretization of those goals is mostly influenced by the domestic (political and socioeconomic) context, and based on existing sectoral policy processes.

In contrast to the thematic areas of the policy goals, the international organizations' impact with regard to concrete policy instruments seems much weaker. Very few concrete examples are found. The case of Quebec is an exception. The government of Quebec shows a genuine effort for policy learning. In the design of some of the instruments of its sustainable development policy, it frequently emphasizes that it has learned from foreign experiences, including from other Canadian provinces, from national governments and from international organizations (Gouvernement du Québec 2004: 12). ${ }^{24}$ The sustainable development indicators are a case in point (MDDEP 2010). Interviews reveal that the government of Quebec gathered most inspiration from the work on indicators by the OECD and the EU's Eurostat (see also Audet and Gendron 2010; Gendron et al. 2009: 16). That finding shows that a government does not need to be associated with an international organization in order to be influenced by it, which is not expected by the literature. The promotion of policy models by international organizations, in this case the EU, exceeds the scope of its member states. ${ }^{25}$ Flanders also developed a set of sustainable development indicators derived from Eurostat. In the other cases, no concrete international influence on policy instruments was found.

In assessing the legitimacy pressures exerted by international organizations, I must refer back to the discussion on the issuance of SDSs. It was stated that only Quebec and Flanders explicitly invoke international commitments to justify their SDSs. The issue is linked to the ambition expressed by subnational governments to pertain to an international community. Before assessing this issue, it must be underlined that many subnational governments attempt to play a role or at least be present in multilateral decision-making for sustainable development. All cases are active in transnational networks of subnational governments. ${ }^{26}$ Those networks give subnational governments the opportunity to be present in the multilateral arena outside of their national context (Happaerts et al. 2010b). Flanders and Wallonia, in addition, have many opportunities to influence multilateral decision-making through

\footnotetext{
24 For instance, Quebec has copied several elements from the Canadian federal sustainable development policy, such as the creation of a Sustainable Development Commissioner (Happaerts 2010a: 24).

${ }^{25}$ Also other examples of the EU's influence on Quebec can be found. For instance, in a reference to the EU's climate package, Quebec has recently fixed the target of a $20 \%$ reduction of greenhouse gases by 2020 (Québec International 2009).

${ }^{26}$ An example is nrg4SD (cf footnote 10). Flanders co-founded that network and is still one of its most active members (Happaerts et al. 2010a: 136). Also Wallonia participated at the Gauteng event and has always been a member of nrg4SD (Happaerts et al. 2010b). North Rhine-Westphalia joined nrg4SD shortly after its creation, but withdrew after 2005 (Happaerts et al. 2010a: 140). Quebec joined nrg4SD in 2010. Besides nrg4SD, those four governments are also active in many other transnational networks, such as The Climate Group's States and Regions Alliance. North Holland participates in less networks, but it is an active member of the Conference of Peripheral Maritime Regions in Europe (CPMR) and its subgroup, the North Sea Commission.
} 
the Belgian framework (Van den Brande et al. 2011). The Belgian subnational entities can conduct an external policy for those policy issues that fall within their competences. That implies that they can include representatives in national delegations for international negotiations and that they can 'speak' at the international level. Quebec and North Rhine-Westphalia have some opportunities to be included in national delegations to international meetings, but those are very limited (Happaerts and Van den Brande 2010: 14, 17). The opportunities that subnational governments have to be present at the international level can be used for the purpose of identity politics. Flanders, for instance, attaches importance to mechanisms that bypass the Belgian context and that give it visibility in the multilateral arena as an entity in itself, and not as a part of the Belgian delegation (Happaerts et al. 2010a: 137). One of the most important goals of the Flemish sustainable development policy is to achieve greater visibility in the global and European sustainable development debate (Peeters 2009: 28), in line with Flanders's ambition for an active foreign policy (Vlaamse Regering 2009: 91). Similarly, for Quebec-one of the most visible non-state actors on the international scene (Michaud 2009: 185)-the development of international relations has traditionally been an important element of its identity-building (Paquin 2005: 133). Those identity politics are visible in the internal sustainable development policy of Quebec as well. In its policy discourse, the government frequently emphasizes that Quebec is among the very few 'states' (États) that have passed a sustainable development act. That fits in the discourse on leadership that has been prominent since the return to power of the Liberals in 2003. The government wants to profile Quebec as the leading 'state' in North America with regard to sustainable development, and issues such as climate change (Gouvernement du Québec 2004: 6; PLQ 2007: 5, 61; Québec International 2009). In doing so, Quebec presents its sustainable development policy as an example to learn from. That is illustrated by the fact that the government participates as a reviewer in the peer review process of the OIF (see footnote 9). In the OIF, the international organization of the francophone world, Quebec has its seat among more than 50 nation-states.

\section{COMPARATIVE PATTERNS AND CONCLUSIONS}

The paper has shown that subnational governments do take global sustainable development governance into account, although they are ignored by the international policy documents and not recognized in multilateral decision-making. However, the international developments do not speak to all subnational governments to the same degree. Three groups can be distinguished among the five cases analyzed here. The first group consists of Flanders and Quebec, which take global sustainable development governance most into account. Flanders and Quebec answer to the international call to develop an SDS, they follow the reporting procedures and they translate the norms and rules of the international regime into their policies. In addition, they are inspired by the promotion of policy models by international organizations. At the other end of the continuum, we find the Dutch province of North Holland, which explicitly states that it does not feel responsible for international policy. Wallonia and North Rhine-Westphalia form a second group between those two extremes. In some aspects, Wallonia was equally influenced by international developments as Flanders-especially regarding the influence coming from the EU-but those international developments did not have the same compelling effect 
(illustrated by the fact that Wallonia still does not have an SDS). As for North RhineWestphalia, it refers more to international governance processes than North Holland does, but it does not feel directly addressed by them as Flanders and Quebec do.

The analysis confirms the hypothesis that the presence of territorial identities explains to a certain degree why and how subnational governments are influenced by international developments. The fact that the strongest influence is observed in Flanders and Quebec is explained by the legitimacy pressures to which those two governments are obviously very susceptible. Flanders and Quebec both have a strong territorial identity, which they are eager to express at the international level in order to be recognized as a legitimate actor. The territorial identity of Wallonia is much weaker (cf Billiet et al. 2006), and non-existent in North Rhine-Westphalia and North Holland.

The influence of global sustainable development governance on subnational governments is also determined by the participation of those governments in international processes. That is illustrated by the fact that Quebec was already influenced by the Brundtland Report (of which it financed the French translation), North Rhine-Westphalia by the Rio Summit (at which North Rhine-Westphalian representatives participated) and Flanders not before Johannesburg (since it did not have the opportunity to participate in multilateral decision-making before 1993). The active participation in multilateral decision-making on sustainable development and in procedures such as national reporting, brings about an open and receptive attitude towards international policy developments. Subnational governments that are actively involved, become familiar with the international discourse on sustainable development and easily pick up on trends with regard to sustainable development policies. The importance of that dynamic is clear in the cases of Quebec and Flanders. Interviews in Quebec suggest that the follow-up of international developments provided expertise on sustainable development within the administration, which proved valuable when the government decided to launch a sustainable development policy in 2003. In Flanders, the institutionalization of the sustainable development policy was to a significant degree directed by the international policy agenda-e.g. through the establishment of the administrative working group on sustainable development, which dedicated much of its time in the initial years to the follow-up of international policy developments. The difference between Flanders and Wallonia in this regard demonstrates that the constitutional opportunities to be involved in multilateral decision-making are not the decisive factor; it also depends on the political will to use those opportunities. That suggests that the strength of legitimacy pressures is not determined by the emitting institutions, but by the receiving government. It is the latter's domestic context that decides whether international legitimacy pressures are taken into account.

The analysis furthermore showed that, with respect to policy content, the international influence is stronger on general characteristics than on specific aspects of the sustainable development policies. International developments play a role in triggering sustainable development policies (although that triggering role is often indirect), they have a strong impact on policy framing, and they influence the themes of policy goals. In contrast, their impact is much less strong with regard to operational goals and instruments. The analysis also suggests that international 
influences are always used in such a way that they accommodate existing domestic priorities. The fact that the international influence is stronger at the general level could be explained, in part, by the character of sustainable development as a metapolicy, meant to guide the development of more specific policies. But even as a meta-policy, the internationally developed norm of sustainable development triggers concrete initiatives at the subnational level.

The theoretical approach that was constructed proved to be a useful framework for this analysis. The international mechanisms of policy convergence-i.e. international harmonization and transnational communication-complemented with insights from regime theory and the globalization literature, were appropriate for the study of sustainable development, which is an outside-in policy characterized to a large extent by soft-law measures. In addition, it allowed the consideration of subnational policies as units of analysis. It has shown that subnational governments to a varying degree take into account international governance processes which are above all intended for nation-states. In practice, however, it appears that the two influence mechanisms are partly linked to each other. That is because the international sustainable development regime entails mostly soft-law measures, for which legitimacy pressures become the principal device of compliance. Although the analytical distinction is justified because of a different perspective implied by the two mechanisms, the norms and principles of the sustainable development regime are in fact strongly associated with the normative discourse of international organizations.

Further research should take into account other factors of which the importance is suggested by the analysis, but that could not be elaborated in this paper. First, the degree of autonomy of subnational governments and the specific competences attributed to each of them should be studied in relation to their sustainable development policies. The large divergence between the results of North Holland and the other cases suggest that the difference in degree of self-rule plays a role, although it is certainly not the only decisive factor, as this paper shows. Second, increased attention should be given to the specific political and socioeconomic context of each case, which determines how international influences are translated. My analysis furthermore suggests that a willing political actor is needed in order for international influences to materialize (illustrated by the return to power of the Liberals in Quebec and the presence of the Green party in North Rhine-Westphalia's coalition).

Finally, the analysis suggests that the global summits of Rio and Johannesburg in general have a greater resonance than the day-to-day work of international organizations, although the effects of summits can be belated or indirect. That findings hints at the importance of the future Rio +20 Summit in 2012, which is currently being prepared by UN member states. Although the organization of the new summit was greeted with scepticism by some, it could create a new momentum for sustainable development, and even if its outcome would not be considered an absolute success, it will probably trigger new initiatives at the subnational level of governance. 


\section{REFERENCES}

Abbott, Kenneth W., and Duncan Snidal. 2000. Hard and Soft Law in International Governance. International Organization 54 (3): 421-456.

Andresen, Steinar. 2007. The effectiveness of UN environmental institutions. International Environmental Agreements: Politics, Law and Economics 7: 317336.

Assemblée Nationale. 2006. Loi sur le développement durable (Projet de loi $n^{\circ} 118$ ). Québec: Éditeur officiel du Québec.

Audet, René, and Corinne Gendron. 2010. The Social and Political Construction of Sustainable Development in Quebec. Paper read at the workshop 'Comparative Subnational Sustainable Development Politics', 23 June, at Leuven.

Barkin, J. Samuel. 2006. International Organization: Theories and Institutions. New York \& Houndmills: Palgrave Macmillan.

Bennett, Colin J. 1988. Different Processes, One Result: The Convergence of Data Protection Policy in Europe and the United States. Governance 1 (4): 415-441.

- 1991. Review Article: What Is Policy Convergence and What Causes It? British Journal of Political Science 21 (4): 215-233.

Bernstein, Steven, and Benjamin Cashore. 2000. Globalization, Four Paths of Internationalization and Domestic Policy Change: The Case of EcoForestry in British Columbia, Canada. Canadian Journal of Political Science XXXIII (1): 6799.

Billiet, Jaak, Bart Maddens, and André-Paul Frognier. 2006. Does Belgium (Still) Exist? Differences in Political Culture between Flemings and Walloons. West European Politics 29 (5): 912-932.

Borghetto, Enrico, and Fabio Franchino. 2010. The role of subnational authorities in the implementation of EU directives. Journal of European Public Policy 17 (6): 759-780.

Brans, Marleen, Pedro Facon, and Dieter Hoet. 2003. Beleidsvoorbereiding in een lerende overheid. Stand van zaken in en uitdagingen voor de Belgische federale overheid. Gent: Academia Press.

Bruyninckx, Hans. 2006. Sustainable development: the institutionalization of a contested policy concept. In Palgrave advances in international environmental politics, edited by M. M. Betsill, K. Hochstetler and D. Stevis. Houndmills: Palgrave Macmillan.

Carter, Caitríona, and Romain Pasquier. 2010. Conclusions. Regional \& Federal Studies 20 (3): 425-430.

Cordonier Segger, Marie-Claire. 2004. Significant developments in sustainable law and governance: A proposal. Natural Resources Forum 28: 61-74.

Council of the EU. 2006. Review of the EU Sustainable Development Strategy (EU SDS) - Renewed Strategy. Brussels: Council of the European Union.

Council of the European Union. 2006. Review of the EU Sustainable Development Strategy (EU SDS) - Renewed Strategy. Brussels: Council of the European Union.

Daviter, Falk. 2007. Policy Framing in the European Union. Journal of European Public Policy 14 (4): 654-666. 
Death, Carl. 2011. Summit theatre: exemplary governmentality and environmental diplomacy in Johannesburg and Copenhagen. Environmental Politics 20 (1): 119.

European Commission. 2002. A European Union Strategy for Sustainable Development. Luxembourg: Office for Official Publications of the European Communities.

European Union. 2010. Consolidated Version of the Treaty on the Functioning of the European Union (Official Journal of the European Union, 30 March 2010). Luxembourg: Publications Office of the European Union.

Eurostat. 2011. Regional statistics. European Commission [cited 21 Jan 2011]. Available from http://epp.eurostat.ec.europa.eu/portal/page/portal/region cities/regional statistic s/data/database.

Fleurke, Frederik, and R. Willemse. 2006. The European Union and the Autonomy of Sub-national Authorities: Towards an Analysis of Constraints and Opportunities in Sub-national Decision-making. Regional \& Federal Studies 16 (1): 83-98.

Franck, Thomas M. 1990. The Power of Legitimacy Among Nations. New York \& Oxford: Oxford University Press.

The Gauteng Declaration. 2002. Johannesburg. Available from http://www.nrg4sd.org/multimedia-library.

Gendron, Corinne, Richard Janda, Marie-Andrée Caron, Olga Navarro-Flores, Annie Rochette, Véronique Bisaillon, Philip Duguay, Sarah Gagnon-Turcotte, Chantal Hervieux, and Emilie White. 2009. Comprendre, évaluer, informer et décider : des indicateurs de développement durable pour le Québec (Mémoire de la Chaire de responsabilité sociale et de développement durable et du Centre de droit international du développement durable déposé à la Commission des transports et de l'environnement de l'Assemblée nationale du Québec). Montréal: Chaire de responsabilité sociale et de développement durable \& Centre de droit international du développement durable. Available from http://www.crsdd.uqam.ca/Pages/cahiers.aspx.

George, Alexander L., and Andrew Bennett. 2005. Case Studies and Theory Development in the Social Sciences. Cambridge, MA \& London: MIT Press.

Gouvernement du Québec. 1996. Mise en oeuvre d'Action 21. Exemples d'initiatives du gouvernement du Québec en matière de développement durable. Québec: Direction de la promotion du développement durable, Ministère de l'Environnement et de la Faune. Available from http://www.mddep.gouv.qc.ca/developpement/etat/action21.pdf.

- 2002. Rapport du Québec sur le développement durable (Présenté au Sommet mondial sur le développement durable). Québec: Comité interministériel sur le développement durable. Available from http://www.mddep.gouv.qc.ca/developpement/etat/rapportqc.pdf.

- 2004. Plan de développement durable du Québec. Document de consultation. Québec: Bibliothèque nationale du Québec. Available from http://www.mddep.gouv.qc.ca/developpement/2004-2007/plan-consultation.pdf.

- 2007. Un projet de société pour le Québec. Stratégie gouvernementale de développement durable 2008-2013. Québec: Bibliothèque et Archives nationales du Québec. Available from http://www.mddep.gouv.qc.ca/developpement/strategie gouvernementale/strat g ouv.pdf. 
2009. À propos du développement durable [cited 18 Dec 2009]. Available from http://www.mddep.gouv.qc.ca/developpement/definition.htm.

- 2010. Indicateurs québécois de développement durable (Document synthèse). Québec: Ministère du Développement durable, de l'Environnement et des Parcs, Bureau de coordination du développement durable. Available from http://www.mddep.gouv.qc.ca/developpement/indicateurs/index.htm.

Happaerts, Sander. 2010a. Sustainable development and degrees of autonomy. The challenge of vertical policy integration from the perspective of North Holland, North Rhine-Westphalia, Flanders and Quebec (Working Paper $\left.n^{\circ} 15\right)$. Leuven: Steunpunt Duurzame Ontwikkeling. Available from http://www.steunpuntdo.be/E SDO publ CoEfSD.htm.

- 2010b. Sustainable development in Wallonia: trial and error along two tracks of governance (Working Paper $\mathrm{n}^{\circ}$ 20). Leuven: Steunpunt Duurzame Ontwikkeling. Available from http://www.steunpuntdo.be/E SDO publ CoEfSD.htm.

Happaerts, Sander, Simon Schunz, and Hans Bruyninckx. 2011. Federalism and Intergovernmental Relations: The Multi-level Politics of Climate Change Policy in Belgium (Working Paper No. 58). Leuven Centre for Global Governance Studies. Available from http://www.ghum.kuleuven.be/ggs/nieuw/pages/publications/working papersS.ht $\underline{\mathrm{ml}}$.

Happaerts, Sander, and Karoline Van den Brande. 2010. Sustainable Development between International and Domestic Forces. The Policy Experiences of Quebec, North Rhine-Westphalia and Flanders (Working Paper $n^{\circ} 18$ ). Leuven: Steunpunt Duurzame Ontwikkeling. Available from http://www.steunpuntdo.be/E SDO publ CoEfSD.htm.

Happaerts, Sander, Karoline Van den Brande, and Hans Bruyninckx. 2010a. Governance for Sustainable Development at the Inter-subnational Level: The Case of the Network of Regional Governments for Sustainable Development (nrg4SD). Regional \& Federal Studies 20 (1): 127-149.

- 2010b. Subnational governments in transnational networks for sustainable development. International Environmental Agreements: Politics, Law and Economics Online First (DOI 10.1007/s10784-010-9128-4).

Hill, Jonathan D., and Thomas M. Wilson. 2003. Identity Politics and the Politics of Identities. Identities: Global Studies in Culture and Power 10 (1): 1-8.

Holzinger, Katharina, and Christoph Knill. 2005. Causes and conditions of crossnational policy convergence. Journal of European Public Policy 12 (5): 775-796.

- 2008. The Interaction of Competition, Co-operation and Communication: Theoretical Analysis of Different Sources of Environmental Policy Convergence. Journal of Comparative Policy Analysis: Research and Practice 10 (4): 403-425.

Holzinger, Katharina, Christoph Knill, and Thomas Sommerer. 2008. Environmental Policy Convergence: The Impact of International Harmonization, Transnational Communication, and Regulatory Competition. International Organization 62: 55387.

Hooghe, Liesbet, Gary Marks, and Arjan H. Schakel. 2008a. Operationalizing Regional Authority: A Coding Scheme for 42 Countries, 1950-2006. Regional \& Federal Studies 18 (2-3): 123-142.

- 2008b. Special Issue: Regional Authority in 42 Countries, 1950-2006: A Measure and Five Hypotheses. Regional \& Federal Studies 18 (2-3). 
Institut de l'énergie et de l'environnement de la Francophonie (IEPF). 2010. Élaboration et mise en oeuvre des SNDD. Organisation internationale de la Francophonie [cited 15 Dec 2010]. Available from http://www.iepf.org/programmes/projet.php?id=72.

Institut de la Statistique du Québec (ISQ). 2008a. Le bilan démographique du Québec (Édition 2008). Québec: Gouvernement du Québec. Available from http://www.stat.gouv.qc.ca/publications/demograp/pdf2008/bilan2008.pdf.

- 2008b. Le Québec chiffres en main (Édition 2008). Québec: Gouvernement $\mathrm{du} \quad$ Québec. Available from http://www.stat.gouv.qc.ca/publications/referenc/pdf2008/QCM2008 fr.pdf.

2010. Databank of Official Statistics on Québec. Gouvernement du Québec [cited 1 Nov 2010]. Available from http://www.bdso.gouv.qc.ca/.

Jänicke, Martin, Helge Jörgens, Kirsten Jörgensen, and Ralf Nordbeck. 2001. Governance for Sustainable Development in Germany: Institutions and Policy Making. OECD. Available from http://www.oecd.org/dataoecd/27/32/1828117.pdf.

Jörgensen, Kirsten. 2002. Ökologisch nachhaltige Entwicklung im föderativen Staat. Das Beispiel der deutschen Bundesländer. Berlin: Forschungsstelle für Umweltpolitik.

Keating, Michael. 1999. Regions and International Affairs: Motives, Opportunities and Strategies. Regional \& Federal Studies 9 (1): 1-16.

Keck, Margaret E., and Kathryn Sikkink. 198. Activists beyond Borders. Advocacy Networks in International Politics. Ithaca \& London: Cornell University Press.

Kern, Kristine, Claudia Koll, and Malte Schophaus. 2007. The Diffusion of Local Agenda 21 in Germany: Comparing the German Federal States. Environmental Politics 16 (4): 604-624.

Knill, Christoph. 2005. Introduction: Cross-national policy convergence: concepts, approaches and explanatory factors. Journal of European Public Policy 12 (5): 764-774.

Kraemer, R. Andreas, Anneke Klasing, and Ingmar von Homeyer. 2003. The EU Open Method of Co-ordination: Risks \& Chances for Environmental Policy. Paper read at the Conference 'Sustainable Development in an Enlarged Union - Linking National Strategies \& Strengthening European Coherence', April, at Vienna.

Krasner, Stephen D. 1982. Structural causes and regime consequences: regimes as intervening variables. International Organization 36 (2): 185-205.

Lafferty, William M. 2004. Introduction: form and function in governance for sustainable development. In Governance for Sustainable Development. The Challenge of Adapting Form to Function, edited by W. M. Lafferty. Cheltenham \& Northampton: Edward Elgar.

Landesregierung NRW. 2002. Agenda Konferenzen 2002. Dokumentation. Düsseldorf: Ministerium für Umwelt und Naturschutz, Landwirtschaft und Verbraucherschutz des Landes Nordrhein-Westfalen.

Landtag NRW. 1998. Agenda 21 NRW - Bündnis für Umwelt, Innovation und Beschäftigung (Plenarprotokoll 12/96, 11.09.1998). Düsseldorf: Landtag Nordrhein-Westfalen. Available from http://www.landtag.nrw.de/portal/WWW/dokumentenarchiv/Dokument/MMP1296.pdf.

- 2002. Regierungserklärung des Ministerpräsidenten (Plenarprotokoll 13/74, 20.11.2002). Düsseldorf: Landtag Nordrhein-Westfalen. Available from 
http://www.landtag.nrw.de/portal/WWW/dokumentenarchiv/Dokument/MMP13-

74.pdf.

Lecours, André. 2002. Paradiplomacy: Reflections on the Foreign Policy and International Relations of Regions. International Negotiation 7 (1): 91-114.

Leterme, Yves. 2004. Vlaanderen, het Noorden én het Zuiden duurzaam ontwikkelen. Beleidsnota Duurzame Ontwikkeling 2004-2009. Brussel: Ministerie van de Vlaamse Gemeenschap. Available from http://www2.vlaanderen.be/duurzameontwikkeling/documenten.htm.

Marcussen, Martin. 2004a. Multilateral surveillance and the OECD: playing the idea game. In The OECD and European Welfare States, edited by K. Armingeon and M. Beyeler. Cheltenham \& Northampton: Edward Elgar.

- 2004b. OECD Governance through Soft Law. In Soft Law in Governance and Regulation. An Interdisciplinary Analysis, edited by U. Mörth. Cheltenham: Edward Elgar.

Marks, Gary, Liesbet Hooghe, and Arjan H. Schakel. 2008. Measuring Regional Authority. Regional \& Federal Studies 18 (2-3): 111-121.

Michaud, Nelson. 2009. Le Québec et ses relations internationales: impacts sur le système fédéral et sur le système international. In Le fédéralisme en Belgique et au Canada. Comparaison sociopolitique, edited by B. Fournier and M. Reuchamps. Bruxelles: De Boeck.

Ministère du Développement durable, de l'Environnement et des Parcs (MDDEP). 2010. Indicateurs québécois de développement durable (Document synthèse). Québec: Gouvernement du Québec. Available from http://www.mddep.gouv.qc.ca/developpement/indicateurs/index.htm.

Ministerium für Umwelt und Naturschutz; Landwirtschaft und Verbraucherschutz des Landes Nordrhein-Westfalen (MUNLV). 2005. Agenda 21 NRW. Gemeinsame Ideen mit Zukunft. Zusammenfassender Bericht des Landesregierung zur Nachhaltigen Entwicklung in NRW. Düsseldorf: MUNLV.

Niestroy, Ingeborg. 2005. Sustaining Sustainability. A benchmark study on national strategies towards sustainable development and the impact of councils in nine EU member states, EEAC series, Background study no. 2. Utrecht: Lemma.

O'Toole, Laurence J., Jr. 2004. Implementation theory and the challenge of sustainable development: the transformative role of learning. In Governance for Sustainable Development. The Challenge of Adapting Form to Function, edited by W. M. Lafferty. Cheltenham \& Northampton: Edward Elgar.

OECD. 2001. Policies to Enhance Sustainable Development. Paris: OECD Publications.

- 2002a. Governance for Sustainable Development. Five OECD Case Studies. Paris: OECD Publications.

- 2002b. Improving Policy Coherence and Integration for Sustainable Development. A checklist (Policy Brief). OECD Observer. Available from www.oecd.org/publications/Pol brief.

OECD, and UNDP. 2002. Sustainable Development Strategies. A Resource Book. Edited by B. Dalal-Clayton and S. Bass. London \& Sterling, VA: Earthscan Publication Ltd.

Palermo, Francesco, and Alessandro Santini. 2004. From NUTS to Constitutional Regions: Addressing EU Regions in the EU Framework. In An Ever More Complex Union. The Regional Variable as Missing Link in the EU Constitution?, edited by R. Toniatti, F. Palermo and M. Dani. Baden Baden: Nomos. 
Paquin, Stéphane. 2003. Paradiplomatie identitaire et diplomatie en Belgique fédérale: le cas de la Flandre. Canadian Journal of Political Science 36 (3): 621642.

- 2005. Les actions extérieures des entités subétatiques: quelle signification pour la politique comparée et les relations internationales ? Revue Internationale de Politique Comparée 12 (2): 129-142.

Parti Libéral du Québec (PLQ). 2007. S'unir pour réussir le Québec de demain (Plan d'action 2007-2012. Deuxième mandat du gouvernement du Parti libéral du Québec). Montréal \& Québec: Parti Libéral du Québec.

Peeters, Kris. 2009. Beleidsnota 2009-2014 Algemeen Regeringsbeleid. Brussel: Vlaamse Regering. Available from http://www.vlaanderen.be/beleidsnotas.

Provincie Noord-Holland. 2007. Krachtig, in Balans. Collegeprogramma 2007-2011. Haarlem: Provincie Noord-Holland. Available from http://www.noordholland.nl/web/show/id=170078.

Québec International. 2009. -20\% : la cible du Québec pour 2020 [cited 23 November 2009]. Available from http://www.mri.gouv.qc.ca/fr/ scripts/Actualites/ViewNew.asp?NewID=7159\&lang =fr.

Quental, Nuno, Júlia M. Lourenço, and Fernando Nunes da Silva. 2011. Sustainable Development Policy: Goals, Targets and Political Cycles. Sustainable Development 19 (1): 15-29.

Risse-Kappen, Thomas. 1996. Exploring the Nature of the Beast: International Relations Theory and Comparative Policy Analysis Meet the European Union. Journal of Common Market Studies 34 (1): 53-80.

Rose, Richard. 1993. Lesson-drawing in Public Policy. A Guide to Learning Across Time and Space. Chatham: Chatham House Publishers.

Schön, Donald A., and Martin Rein. 1994. Frame Reflection. Toward the Resolution of Intractable Policy Controversies. New York: Basic Books.

Spangenberg, Joachim H. 2010. A European Methodology for Sustainable Development Strategy Reviews. Environmental Policy and Governance 20: 123134.

SPD, and Die Grünen. 2000. Der Neubeginn: Eine Allianz für das Zukunftsland Nordrhein-Westfalen (Koalitionsvertrag 2000-2005). Düsseldorf: NRWSPD \& Bündnis 90/Die GRÜNEN NRW. Available from http://www.juelkenbeck.net/nordumgehung/Koalitionsvertrag NRW2000.pdf.

Steurer, Reinhard, and Markus Hametner. 2010. Objectives and Indicators in Sustainable Development Strategies: Similarities and Variances across Europe. Sustainable Development DOI: 10.1002/sd.501.

Swenden, Wilfried, and Maarten Theo Jans. 2006. 'Will It Stay or Will It Go?' Federalism and the Sustainability of Belgium. West European Politics 29 (5): 877894.

Tarasofsky, Richard. 2007. Canada's Progress in Addressing the Strategic Imperatives set out in "Our Common Future". Winnipeg: International Institute for Sustainable Development. Available from http://www.iisd.org/pdf/2007/facing canada progress.pdf.

Tews, Kerstin, Per-Olof Busch, and Helge Jörgens. 2003. The diffusion of new environmental policy instruments. European Journal of Political Research 42: 569-600. 
Trubek, David M., Patrick Cottrell, and Mark Nance. 2005. "Soft Law", "Hard Law", and European Integration: Toward a Theory of Hybridity. University of WisconsinMadison.

United Nations Conference on Environment and Development (UNCED). 1992a. Agenda 21: Programme of Action for Sustainable Development. United Nations Department of Public Information.

— 1992b. The Rio Declaration on Environment and Development. New York: United Nations.

United Nations Department of Economic and Social Affairs (UNDESA). 2002a. Johannesburg Summit 2002. Belgium Country Profile. New York: United Nations. Available from http://www.un.org/esa/agenda21/natlinfo/wssd/belgium.pdf.

—. 2002b. Johannesburg Summit 2002. Canada Country Profile. New York: United Nations. Available from http://www.un.org/esa/agenda21/natlinfo/wssd/canada.pdf.

—. 2002c. Johannesburg Summit 2002. Germany Country Profile. New York: United Nations. Available from http://www.un.org/esa/agenda21/natlinfo/wssd/germany.pdf.

- 2002d. Johannesburg Summit 2002. Netherlands Country Profile. New York: United Nations. Available from http://www.un.org/esa/agenda21/natlinfo/wssd/netherlands.pdf.

- 2008a. Commission on Sustainable Development. About CSD. United Nations [cited 4 January 2008]. Available from http://www.un.org/esa/sustdev/csd/aboutCsd.htm.

- 2008b. Indicators of Sustainable Development [cited 25 September 2008]. Available from http://www.un.org/esa/sustdev/natlinfo/indicators/isd.htm.

Van den Brande, Karoline. 2010. Flanders in the UN and OECD Discussions on Sustainable Development. An Assessment of Presence, Visibility and Policy Impact (Working Paper $n^{\circ} 21$ ). Leuven: Steunpunt Duurzame Ontwikkeling. Available from http://www.steunpuntdo.be/E SDO publ CoEfSD.htm.

- 2011a. The European Union in the Commission on Sustainable Development (in press). In The European Union and Multilateral Governance: Assessing EU Participation in United Nations Human Rights and Environmental Fora, edited by J. Wouters, H. Bruyninckx, S. Basu and S. Schunz. Basingstoke: Palgrave Macmillan.

— 2011b. Intergovernmental Cooperation for International Decision-making in Federal Belgium. The Case of Sustainable Development. Paper read at the ISA Annual Convention 2011, 16-19 March, at Montreal.

Van den Brande, Karoline, Sander Happaerts, and Hans Bruyninckx. 2011. MultiLevel Interactions in a Sustainable Development Context. Different routes for Flanders to Decision-Making in the UN Commission on Sustainable Development. Environmental Policy and Governance 21 (1): 70-82.

Vlaams Parlement. 2008. Ontwerp van decreet ter bevordering van duurzame ontwikkeling (Tekst aangenomen door de plenaire vergadering, 9 juli 2008). Brussel: Vlaams Parlement. Available from http://docs.vlaamsparlement.be/docs/stukken/2007-2008/g1629-4.pdf.

Vlaamse Regering. 2006. Samen grenzen ver-leggen. Vlaamse strategie duurzame ontwikkeling (fase 1) (Ontwerptekst goedgekeurd door de Vlaamse Regering). Brussel: Vlaamse Regering. Available from http://do.vlaanderen.be/nlapps/data/docattachments/VSDO 20060928 DEF.pdf. 
- 2009. Een daadkrachtig Vlaanderen in beslissende tijden. Voor een vernieuwende, duurzame en warme samenleving (regeerakkoord Vlaanderen 2009-2014). Brussel: Vlaamse Regering. Available from http://publicaties.vlaanderen.be/eblweb/do/publicatieSessionFacade/publicatieEenvoudigeDetailAction/raadplegen? method=raadplegen\&id=25114.

von Homeyer, Ingmar. 2002. The Impact of Enlargement on EU Environmental Governance. Intereconomics 37 (6): 293-297.

- 2009. The Evolution of EU Environmental Governance. In Environmental Protection: European Law and Governance, edited by J. Scott. Oxford: Oxford University Press.

World Commission on Environment and Development (WCED). 1987. Our Common Future. New York and Oxford: Oxford University Press. 


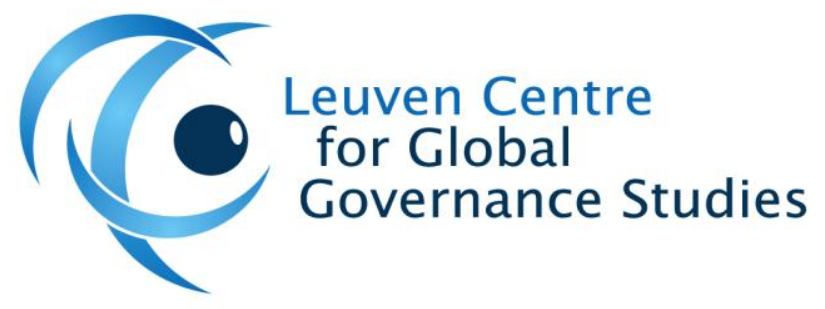

The Leuven Centre for Global Governance Studies is an interdisciplinary research centre of the Humanities and Social Sciences at the Katholieke Universiteit Leuven. It was set up in the Spring of 2007 to promote, support and carry out high-quality international, innovative and interdisciplinary research on global governance. In addition to its fundamental research activities the Centre carries out independent applied research and offers innovative policy advice and solutions to policy-makers on multilateral governance and global public policy issues. In 2010, the Centre has been recognized as a "K.U.Leuven Centre of Excellence".

The Centre brings together talent from throughout the University. It operates on the basis of co-ownership and the strong conviction that interdisciplinary research creates added value to resolve complex multi-faceted international problems. The Centre promotes pioneering projects in law, economics and political science and actively initiates and encourages interdisciplinary, cross-cutting research initiatives in pursuit of solutions to real world problems. The cross-cutting initiatives are thematic projects around which University researchers join forces across disciplines to forge responses to complex global challenges. The cross-cutting initiatives address critical issues in relation to globalization, governance processes and multilateralism, with a particular focus on the following areas: (i) the European Union and global multilateral governance; (ii) trade and sustainable development; (iii) peace and security, including conflict prevention, crisis management and peacebuilding; (iv) human rights, democracy and rule of law.

In full recognition of the complex issues involved, the Centre approaches global governance from a multilevel and multi-actor perspective. The multi-level governance perspective takes the interactions between the various levels of governance (international, European, national, subnational, local) into account, with a particular emphasis on the multifaceted interactions between the United Nations System, the World Trade Organization, the European Union and other regional organizations/actors in global multilateral governance. The multi-actors perspective pertains to the roles and interactions of various actors at different governance levels, these include public authorities, non-governmental organizations and private actors such as corporations.

For more information, please visit the website www.globalgovernancestudies.eu

Leuven Centre for Global Governance Studies

Huis De Dorlodot, Deberiotstraat 34, 3000 Leuven, Belgium

Tel. ++32 16328725 Fax ++32 16373547 info@ggs.kuleuven.be

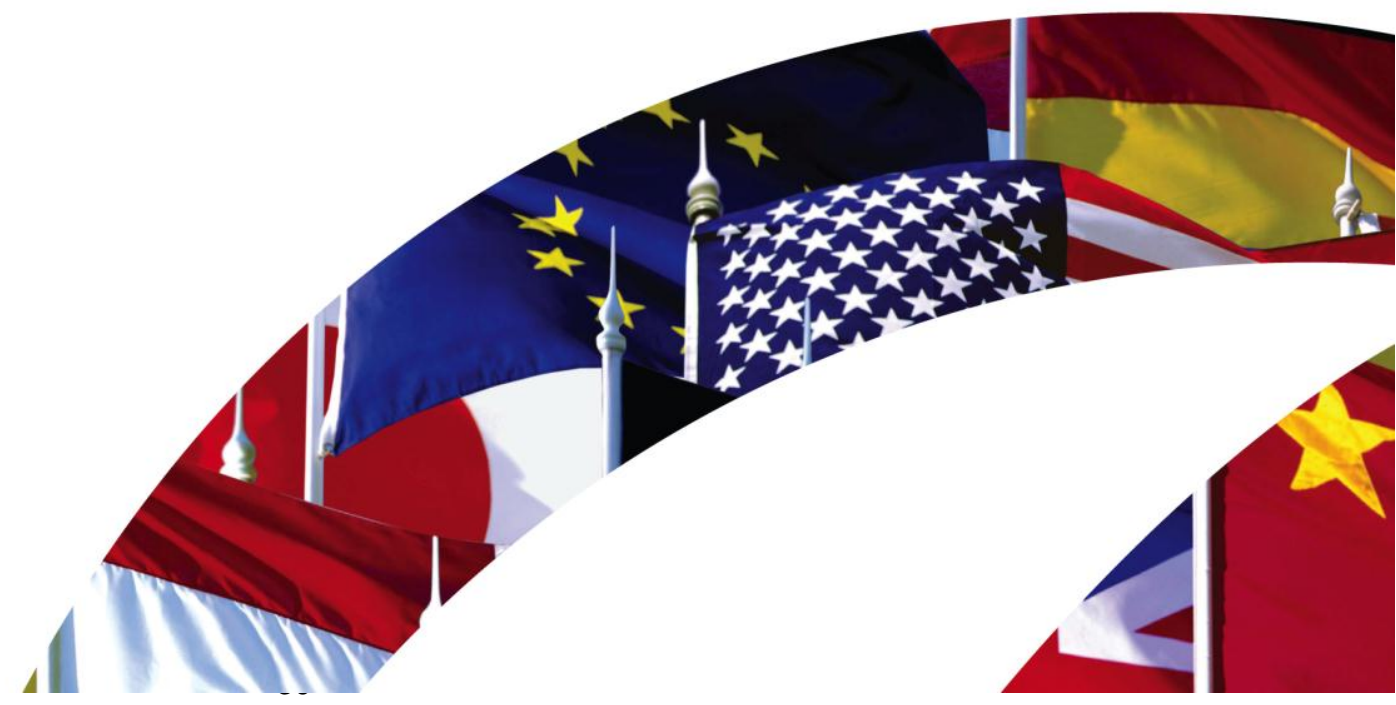

